\title{
EVALUATION OF NEW PROMISING RICE HYBRID AND ITS PARENTAL LINES FOR FLORAL, AGRONOMIC TRAITS AND GENETIC PURITY ASSESSMENT
}

\author{
Galal Anis ${ }^{1}$, Hamada Hassan', Ahmed El-Sherif ${ }^{1}$, Hirofumi Saneoka² and Ayman EL Sabagh ${ }^{3, *}$ \\ ${ }^{1}$ Rice Research Department, Field Crops Research Institute, Agricultural Research Center, 33717, Sakha, Kafr El- \\ Sheikh, Egypt; ${ }^{2}$ Graduate School of Biosphere Science, Hiroshima University, 1-4-4 Kagamiyama, Higashi- \\ Hiroshima, 739-8528, Japan; ${ }^{3}$ Department of Agronomy, Faculty of Agriculture, Kafr El-Sheikh University, Egypt \\ "Corresponding author' e-mail: ayman.elsabagh@agr.kfs.edu.eg
}

Development of new rice hybrids with high-yielding and superior in grain quality is the most important goal to enhance food security as well as to achieve consumer requirements. High seed costs and poor grain quality are the major limiting factors for adoption of hybrid rice. A practical way to improve hybrid seed quality and to increase production is possible to increase the seed setting rate through improving the floral traits for parental lines. In the context, the study was conducted at the Rice Farm and Laboratories of Sakha Agricultural Research Station, Sakha, Kafr El-Sheikh, Egypt in consecutive three rice growing seasons in 2015, 2016 and 2017. The study focused mainly on characterization of the new promising hybrid 'G46A/GZ9399R' and its parental lines. The cytoplasmic male sterile (CMS) line and restorer line were evaluated for twenty-three floral traits that influence outcrossing rate in hybrid rice under two seasons and there was a marked stability for most of these traits. As compared with commercial check variety 'Giza 178', the new promising hybrid 'G46A/GZ9399R' showed its superiority in all agro-morphological traits except plant height. This hybrid was very early, adapted widely and recorded $20.19 \%$ more yield than commercial check variety 'Giza 178 '. Instead, this hybrid produced superiority in all grain quality properties except grain length was medium grain and amylose content was equal for both studied genotypes compared to the check variety. In parallel, the assessment of genetic purity established the SSR markers RM154, RM331, and RM297, amplified alleles specific to differentiate parental lines of hybrid 'G46A/GZ9399R'.

Keywords: Hybrid rice, floral traits, hybrid seed production, genetic purity.

\section{INTRODUCTION}

Rice, Oryza sativa L. is considered the greatest staple crop feeding over half of population of world. At present, the world's population around 6 billion is likely to cross 8 billion by 2030 , which obliges that the rice productivity must improve by $40 \%$ to meet the growing demand (Khush and Brar, 2002; Bhavsar et al., 2017). Rice plays an important role for ensuring food security and poverty alleviation in riceeating countries in addition farmers' income sources for the majority of the world population (Miura et al., 2011) and it is the staple food for the most of the people across the World, who are living in rural and urban areas of tropical and subtropical Asian countries (Cottyn, 2002; Cottyn et al., 2009). To meet the challenge of providing extra rice from appropriate lands, the rice varieties/hybrids with better yield potential and greater yield stability is needed. Hybrid rice technology and exploitation of hybrid vigour that has a yield advantage of $20-25 \%$ over the best inbred varieties led to adoption of this technology over 57\% (17 million hectares) of its rice area (Yuan, 2004). The productivity of rice and thus contribute to self-sufficiency of food supply in rice-growing countries (Cheng et al., 2007).
In Egypt rice production is about 5.8 million tons rough rice, while sustaining self-sufficiency has enabled the country to export as high as 800,000 tons of milled rice annually (USDA, 2016). Although Egypt has been one of the earliest countries for trying to introduce hybrid rice technology, while goal oriented systematic research was initiated in 1995 (Bastawisi et al., 2003). The achievements include identification of many heterotic hybrids for extensive on-farm testing, a large number of hybrids under different stages of testing, near success in the development of parental lines ideally adapted to Egyptian conditions (El-Mowafi et al., 2005). The results of hybrid rice yield trials conducted during 1995 to 2009 confirmed that a number of early maturing hybrids yielded about $20 \%$ more than the best commercial rice varieties. For this reason, the government gave a high priority to develop and use of hybrid rice.

The hybrid rice adoption is extremely restricted, due to its higher seed cost and low hybrid seed production capacity. To enhance and overcome to these challenges, it is necessary to increase the yield of hybrid seed by improving the outcrossing capacity of cytoplasmic male sterile (CMS) lines (Yang et al., 2006; Cheng et al., 2007). Therefore, the characterization of CMS lines for floral traits is one of the essential aspects for 
every breeder and that should be keep in mind while selecting a parental line in hybrid rice breeding program. The extent of outcrossing on cytoplasmic male sterile lines (CMS) is influenced by its floral traits viz., stigma size, stigma exsertion rate, style length and anther size, filament length, pollen number anther ${ }^{-1}$ in pollen parent. The flowering behavior traits influencing outcrossing in rice are time of blooming, number of days of blooming, duration of blooming, duration of floret opening, and angle of floret opening (Ishikawa et al., 2017). During the last ten years, Rice Research and Training Center (RRTC) in Egypt developed a large number of new rice hybrids and their parental lines through testcross nurseries (El-Mowafi et al., 2008; Abd Allah, 2008; Anis, 2013; El-Mowafi et al., 2015; El-Badawy, 2016; Anis et al., 2016 a,b; Anis et al., 2017; Hassan et al., 2017). From the above cited earlier studies, it is confirming that the agromorphological traits have been major components for hybrids identification and the plant description should start from its early maturing up to record high grain yield. Since rice is a self-pollinated crop; therefore, the big challenge for breeders is to produce large-scale pure hybrid seeds for farmers to increase rice production. It has been reported that the yield has been reduced $100 \mathrm{~kg} /$ ha for every $1 \%$ impure hybrid seed (Mao et al., 1996).

Adoption of new bio-technologies for crop improvement and evaluation of hybrid seed genetic purity and agronomical characteristics are the most necessary quality control traits in hybrid seed production (Ansari et al., 2015; Al-Ashkar et al., 2016; Ghori et al., 2016; Bakht et al., 2017). The present investigation was under taken with an objective of characterization and identification of the distinguished features of new promising rice hybrid 'G46A/GZ9399R' and its parental lines for floral, agronomic traits and assessment of genetic purity.

\section{MATERIALS AND METHODS}

Site description of the present research: The experiment was conducted at the Rice Farm and Laboratories of Sakha Agricultural Research Station, Sakha, Kafr El-Sheikh, Egypt during 2015, 2016 and 2017 successive rice growing seasons. The study focused on characterization and comparison of the new promising hybrid 'G46A/GZ9399R' with the cultivated high yielding inbred variety 'Giza 178' (hybrid and conventional rice), screening the floral traits for its parental lines and assessment of genetic purity.

Development history of new promising rice hybrid 'G46A/GZ9399R': Three-line hybrid combination 'G46A/GZ9399R' is one of the best rice hybrids that were developed in Rice Research and Training Center (RRTC) in Egypt through testcross and has a high grain yield as compared with the cultivated hybrid (Anis and El-Sherif, 2014; Anis et al., 2016c). The parental lines of this hybrid are 'G46A' an Indica (CMS) line having Gambiaca cytoplasmic source and 'GZ9399R' an Indica-Japonica local restorer line (Fig. 1).

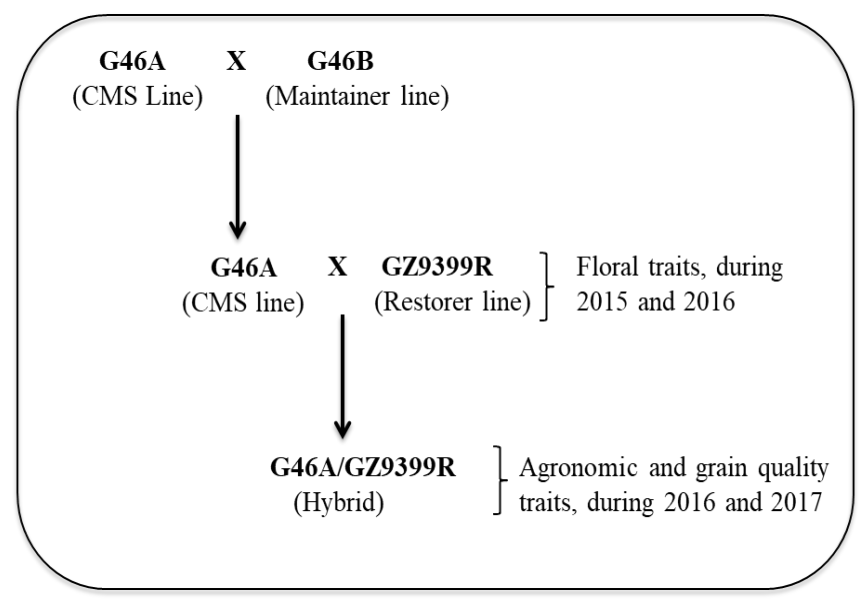

Figure 1. Breeding scheme and work plan used for developing and evaluation of the new hybrid G46A/GZ9399R and its parental lines.

Climatic condition during rice growing seasons: Monthly temperature data of the two years 2015 and 2016 were provided by the Division of Meteorology, (RRTC), Sakha, Kafr El-Sheikh, Egypt (Fig. 2).

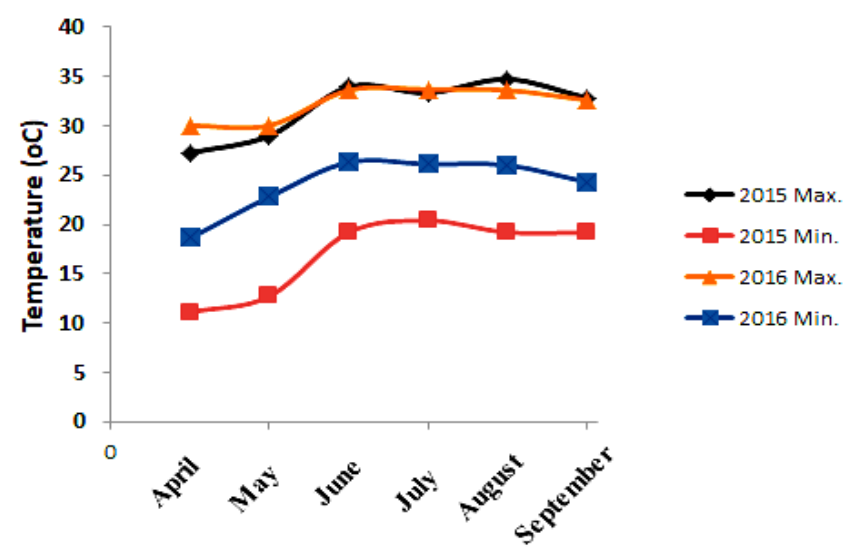

Figure 2. Monthly mean of minimum (Min) and maximum (Max) temperatures during the two rice growing seasons 2015 and 2016.

Experimental procedure: The studied rice genotypes ' $\mathrm{G} 46 \mathrm{~A}$ ', 'G46B', 'GZ9399R' in addition to 'Giza178' as check commercial variety were laid out in a randomized complete block design (RCBD) with three replications. One seedling per hill was transplanted in the main field after 30 days with the spacing of $20 \times 20 \mathrm{~cm}$ between plants in $5 \mathrm{~m}$ long rows. Field and seeding bed management such as fertilization, irrigation, weeding and pests control were done as recommendations for rice crop during the seasons of this study (RRTC, 2013). The parental lines (G46A and GZ9399R) 
Table 1. Details of SSR markers used for amplification in the present study.

\begin{tabular}{|c|c|c|c|c|}
\hline No. & SSR marker & Chr. ${ }^{1}$ & F primer ${ }^{2}$ & R primer ${ }^{3}$ \\
\hline 1 & RM258 & 10 & TGCTGTATGTAGCTCGCACC & TGGCCTTTAAAGCTGTCGC \\
\hline 2 & RM154 & 2 & АCCCTCTCCGCCTCGCCTCCTC & СТCCTCCTCCTGCGACCGCTCC \\
\hline 3 & RM70 & 7 & GTGGACTTCATTTCAACTCG & GATGTATAAGATAGTCCC \\
\hline 4 & RM247 & 12 & TAGTGCCGATCGATGTAACG & CATATGGTTTTGACAAAGCG \\
\hline 5 & RM331 & 8 & GAACCAGAGGACAAAAATGC & CATCATACATTTGCAGCCAG \\
\hline 6 & RM226 & 1 & AGCTAAGGTCTGGGAGAAACC & AAGTAGGATGGGGCACAAGCTC \\
\hline 7 & RM204 & 6 & GTGACTGACTTGGTCATAGGG & GCTAGCCATGCTCTCGTACC \\
\hline 8 & RM297 & 1 & TCTTTGGAGGCGAGCTGAG & CGAAGGGTACATCTGCTTAG \\
\hline 9 & RM331 & 8 & GTAGGAAAGGAAGGGCAGAG & CGATAGATAGCTAGATGTGGCC \\
\hline 10 & RM164 & 5 & TCTTGCCCGTCACTGCAGATATCC & GCAGCCCTAATGCTACAATTCTTC \\
\hline
\end{tabular}

${ }^{1}$ Chromosome; ${ }^{2}$ Forward primer; ${ }^{3}$ Reverse primer

were crossed and evaluated for floral traits during 2015 and 2016 rice seasons.

Data and their recording procedure: Observations were recorded on ten randomly selected plants of each genotype in each replication for various studied traits. The floral traits were measured with a micrometer under a stereo-microscope. Five florets (plants/panicles) per each parental line were used for measurement of stigma length $(\mathrm{mm})$, stigma width $(\mathrm{mm})$, duration of floret opening $(\mathrm{min})$, floret opening angle $\left({ }^{\circ}\right)$, style length $(\mathrm{mm})$, style width $(\mathrm{mm})$, lemma length $(\mathrm{mm})$, lemma width $(\mathrm{mm})$, palea length $(\mathrm{mm})$, palea width $(\mathrm{mm})$, outcrossing rate $(\%)$, pollen sterility rate $(\%)$, panicle exsertion (\%), stigma exsertion (\%), flag leaf length $(\mathrm{cm})$ and flag leaf width $(\mathrm{cm})$ for CMS line (G46A), while, anther length $(\mathrm{mm})$, anther width $(\mathrm{mm})$, pollen fertility $(\%)$, number of pollen grains/anther, filament elongation $(\mathrm{mm})$, flag leaf length $(\mathrm{cm})$ and flag leaf width $(\mathrm{cm})$ for pollen parent ('GZ9399R').

Agronomic traits like; days to heading (day), plant height $(\mathrm{cm})$, panicle length $(\mathrm{cm})$, panicle weight $(\mathrm{g}), 1000$-grain weight $(\mathrm{g})$, number of panicles/plant, spikelet fertility rate (\%) and grain yield ( $\mathrm{t} / \mathrm{ha})$.

Grain quality traits like; grain length (mm), grain width (mm), grain shape $(\mathrm{mm})$, hulling $(\%)$, milling $(\%)$, head rice $(\%)$, elongation (\%), gelatinization temperature, gel consistency, and amylose content $\%$ were recorded for the promising hybrid 'G46A/GZ9399R' and check variety 'Giza 178' during 2016 and 2017 seasons based on the standard evaluation system (SES) of rice (IRRI, 1996).

Pollen fertility and sterility percentage were determined on the basis of the classification developed by Virmani et al. (1997) and Sabar et al. (2007). Number of pollen grains/anther was determined according to Suzuki (1981).

Statistical analysis: Data collected on floral and morphological traits were analyzed by using the standard methods of Panse and Sukhatme, (1984).

Molecular analysis: Twenty seeds from each parental line; GZ9399 and G46A and hybrid were soaked in water at $37^{\circ} \mathrm{C}$ for two days. Fifteen germinated seeds were placed in eppendorf tubes and incubated at $29^{\circ} \mathrm{C}$ for 20 days.
The genomic DNA was isolated from the young seedlings following the standard CTAB method protocol (Luo et al., 2005). A total of 10 SSR markers in Table 1 were selected for parental lines polymorphism testing and the information about these primers were obtained from the previous publications of Tamilkumar et al. (2009), Galal et al. (2014) and Bora et al. (2016).

PCR amplification: Ten primers were selected and used for PCR amplification in this study according to Tamilkumar $e t$ al. (2009), Galal et al. (2014) and Bora et al. (2016). The PCR amplification was performed in a $10-\mu \mathrm{L}$ reaction volume containing $1.5 \mu \mathrm{L}$ of $20.0 \mathrm{ng} / \mu \mathrm{L}$ template genomic DNA, 1.0 $\mu \mathrm{L}$ of $10 \times$ PCR buffer, $0.25 \mu \mathrm{L}$ of $1.0 \mathrm{pmol} / \mu \mathrm{L}$ dNTPs, 1.5 $\mu \mathrm{L}$ of $2.0 \mathrm{pmol} / \mu \mathrm{L}$ primer pairs, $0.06 \mu \mathrm{L}$ of $5.0 \mathrm{U} / \mu \mathrm{L}$ Taq DNA polymerase and $5.69 \mu \mathrm{L}$ of $\mathrm{ddH}_{2} \mathrm{O}$. The amplification protocol consisted of an initial denaturation step $\left(94^{\circ} \mathrm{C}\right.$ for 5 min), followed by 32 cycles of $94^{\circ} \mathrm{C}$ for $30 \mathrm{~s}, 55^{\circ} \mathrm{C}$ for $30 \mathrm{~s}$, and $72^{\circ} \mathrm{C}$ for $1 \mathrm{~min}$. The reactions were completed with a final extension step of $72^{\circ} \mathrm{C}$ for $7 \mathrm{~min}$. The PCR products were separated by $1.5 \%$ agarose gel stained with $\mathrm{Et} \mathrm{Br}$ solution $(1 \mathrm{mg} / \mathrm{l})$. The size of bands was estimated using a ladder. Bands were visualized under UV light in gel documentation systems and captured images were used for further analyses.

\section{RESULTS AND DISCUSSION}

At present, all cytoplasmic male sterile (CMS) lines in hybrid rice breeding program in Egypt produced from China and other countries. On the basis of floral traits, outcrossing rate, agronomic traits, combining ability, grain shape, amylose content, performance of their hybrids and stability, three CMS lines viz. IR69625A, IR68888A and IR58025A with WA cytoplasmic source and one CMS line G46A with Gambiaca cytoplasmic source have been selected for large scale multiplication and utilization under Egyptian conditions. The vast popular of the commercial hybrids are currently based on CMS line IR69625A. This narrow choice of female line is one of the factors limiting higher heterosis and improved quality of hybrids. In previous studies, G46A was crossed with a good number of various genotypes during testcrosses nursery 
to produce new hybrids and CMS lines in adaptive local backgrounds (Anis and El-Sherif, 2014). G46A/GZ9399R as a new promising hybrid was developed with desirable agronomic characteristics (Anis and El-Sherif, 2014; Anis et al., 2016c). During this investigation, we shed light on the characterization of floral, agronomic and grain quality traits of this hybrid and its parental lines.

Evaluation of floral traits: Synchronization in flowering between the parental lines in hybrid seed production is necessary to get higher seed yield because this depends on the amount of pollen supplied from the male parent during flowering period (Mondo et al., 2016). Days to heading was expressed differentially between CMS and restorer lines. The restorer line GZ9399R was earlier than the CMS line G46A under both seasons, but this difference is simple and can be overcome by sowing dates. To achieve the optimum synchronization of flowering to obtain a good outcrossing, the CMS line should flower 1-2 days earlier than the restorer line (Sindhu and Kumar, 2002). Plant height of parental lines in two-line and three-line system plays a significant role in determining the extent of seed set in the hybrid rice seed production (Vishwakarma et al., 2016). The ideal and quality of seed production requires that the pollinator be longer than the female parent. According to the results, the CMS line G46A showed the shortest plant height as compared to restorer line the GZ9399R during both seasons, which shows that the seed production of this hybrid will go smoothly (Table 2 and Figure 3A).

To enhance the efficiency of seed set in (CMS) lines, it is required to study the stigma length and stigma width traits because large stigma size facilitates out crossing rate during hybrid seed production (El-Namaky, 2018). The results revealed that, stigma length of G46A did not vary significantly and it was 1.41 and $1.50 \mathrm{~mm}$ for 2015 and 2016 seasons, respectively. Simultaneously, stigma width was recorded $0.58 \mathrm{~mm}$ during 2015 and $0.66 \mathrm{~mm}$ during 2016 growing season (Table 2; Fig. 3C). The stigma length $>1 \mathrm{~mm}$ had a pronounced influence on increasing the seed set rate of (CMS) lines (Virmani and Athwal, 1973; Oka, 1988; Hasan et al., 2014).

Anther length, anther width, number of pollen grains/anther and filament elongation are the most important floral traits for pollen parent in hybrid rice seed production fields (Mahalingam et al., 2013). In our case study, these traits determined to the restorer line GZ9399R without determining it to the CMS line G46A. The restorer line showed the best values for these four traits because of its stability over two seasons. After the opening of spikelet, the anther filament starts to elongate rapidly, hereby increasing the possibility of outcrossing in the hybrid rice seed production fields. Ishikawa

Table 2. Performance of the hybrid parental lines (G46A and GZ9399R) for different floral traits during 2015 and 2016 growing seasons.

\begin{tabular}{|c|c|c|c|c|}
\hline \multirow[t]{2}{*}{ Floral traits } & \multicolumn{2}{|c|}{ CMS line G46A } & \multicolumn{2}{|c|}{ Restorer line GZ9399R } \\
\hline & 2015 & 2016 & 2015 & 2016 \\
\hline Days to heading (day) & $91.63 \pm 0.71$ & $93.30 \pm 0.80$ & $89.90 \pm 0.44$ & $91.20 \pm 0.82$ \\
\hline Plant height $(\mathrm{cm})$ & $97.96 \pm 0.66$ & $95.73 \pm 0.41$ & $107.76 \pm 1.46$ & $104.56 \pm 0.58$ \\
\hline Stigma length (mm) & $1.41 \pm 0.05$ & $1.50 \pm 0.02$ & $\mathrm{Nm}^{*}$ & $\mathrm{Nm}$ \\
\hline Stigma width (mm) & $0.58 \pm 0.02$ & $0.66 \pm 0.03$ & $\mathrm{Nm}$ & $\mathrm{Nm}$ \\
\hline Anther length (mm) & $\mathrm{Nm}$ & $\mathrm{Nm}$ & $1.73 \pm 0.11$ & $1.77 \pm 0.18$ \\
\hline Anther width (mm) & $\mathrm{Nm}$ & $\mathrm{Nm}$ & $0.44 \pm 0.04$ & $0.40 \pm 0.03$ \\
\hline Number of pollen grains/anther & $\mathrm{Nm}$ & $\mathrm{Nm}$ & $1037.21 \pm 134.5$ & $1092.54 \pm 229.9$ \\
\hline Filament elongation (mm) & $\mathrm{Nm}$ & $\mathrm{Nm}$ & $6.11 \pm 0.23$ & $6.95 \pm 0.13$ \\
\hline Duration of floret opening (min) & $119.38 \pm 3.21$ & $123.33 \pm 1.53$ & $98.36 \pm 8.06$ & $105.53 \pm 8.65$ \\
\hline Floret opening angle $\left(^{\circ}\right)$ & $24.90 \pm 0.78$ & $26.36 \pm 0.35$ & $\mathrm{Nm}$ & $\mathrm{Nm}$ \\
\hline Style length $(\mathrm{mm})$ & $0.87 \pm 0.65$ & $0.93 \pm 0.14$ & $\mathrm{Nm}$ & $\mathrm{Nm}$ \\
\hline Style width (mm) & $0.18 \pm 0.02$ & $0.20 \pm 0.03$ & $\mathrm{Nm}$ & $\mathrm{Nm}$ \\
\hline Lemma length (mm) & $7.40 \pm 0.53$ & $7.66 \pm 0.76$ & $\mathrm{Nm}$ & $\mathrm{Nm}$ \\
\hline Lemma width (mm) & $2.30 \pm 0.10$ & $2.36 \pm 0.21$ & $\mathrm{Nm}$ & $\mathrm{Nm}$ \\
\hline Palea length (mm) & $7.13 \pm 0.32$ & $7.46 \pm 0.73$ & $\mathrm{Nm}$ & $\mathrm{Nm}$ \\
\hline Palea width (mm) & $1.64 \pm 0.10$ & $1.76 \pm 0.15$ & $\mathrm{Nm}$ & $\mathrm{Nm}$ \\
\hline Outcrossing rate $(\%)$ & $17.23 \pm 2.97$ & $19.12 \pm 3.50$ & $\mathrm{Nm}$ & $\mathrm{Nm}$ \\
\hline Pollen fertility (\%) & $\mathrm{Nm}$ & $\mathrm{Nm}$ & $97.48 \pm 2.26$ & $98.11 \pm 1.54$ \\
\hline Pollen sterility (\%) & $100.00 \pm 0.00$ & $99.70 \pm 0.59$ & $\mathrm{Nm}$ & $\mathrm{Nm}$ \\
\hline Panicle exsertion rate $(\%)$ & $58.45 \pm 0.52$ & $63.75 \pm 2.11$ & $\mathrm{Nm}$ & $\mathrm{Nm}$ \\
\hline Stigma exsertion rate $(\%)$ & $10.73 \pm 1.40$ & $11.42 \pm 2.44$ & $\mathrm{Nm}$ & $\mathrm{Nm}$ \\
\hline Flag leaf length $(\mathrm{cm})$ & $36.16 \pm 3.37$ & $33.35 \pm 1.95$ & $44.10 \pm 1.87$ & $46.22 \pm 1.06$ \\
\hline Flag leaf width $(\mathrm{cm})$ & $2.35 \pm 0.18$ & $2.50 \pm 0.23$ & $1.66 \pm 0.12$ & $1.84 \pm 0.76$ \\
\hline
\end{tabular}

* Nm: Not measured 
et al. (2017) reported that, floral morphologies are important factors determining mating systems in rice. Duration of floret opening is a major factor increasing the outcrossing rate in hybrid rice parental lines. The results revealed that, the CMS line G46A gave long time for floret opening compared to the restorer line. Among the two seasons, duration of floret opening trait under 2015 was lower than those of 2016, indicating that this trait may have been influenced by environmental factors especially the differences in temperature. For the CMS lines, floret opening angle, style length, style width, lemma length, lemma width, palea length, palea width and outcrossing rate $(\%)$ are the significant floral traits which play a key role in improving seed set percent (Phukan et al., 2018). These eight traits gave a stabile value for the CMS line G46A under both seasons except floret opening angle $\left(24.90^{\circ}, 26.36^{\circ}\right)$ and outcrossing rate $(17.23$, $19.12 \%)$. Several studies reported that, the environmental factors play a role in the effect on floret opening angle and outcrossing rate (\%) (Abd Allah, 2008; Hasan et al., 2014). Regarding the pollen fertility $(\%)$ for the restorer line GZ9399R, the results were 97.48 and 98.11 (\%) under both seasons, respectively (Table 2; Fig. 3f).
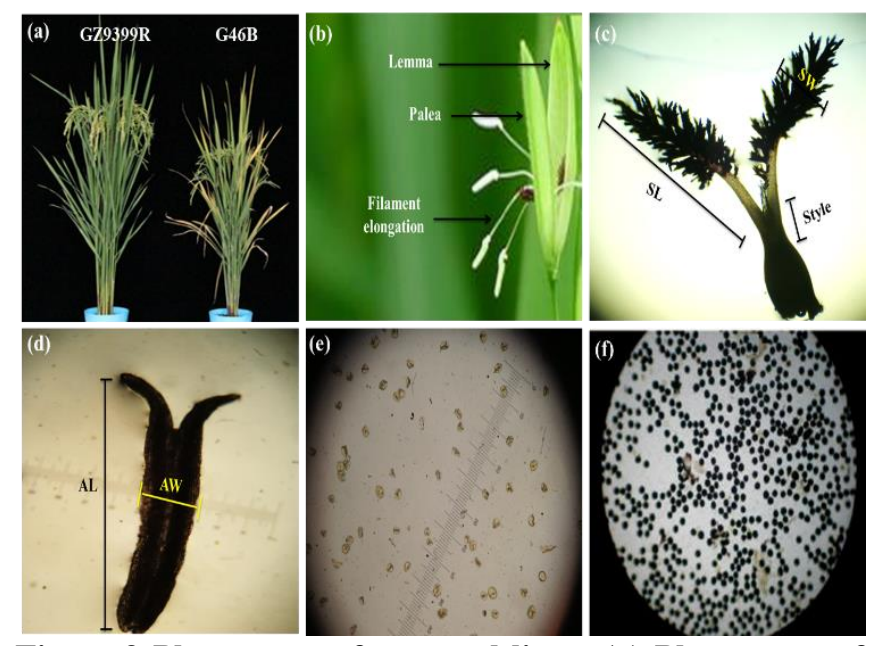

Figure 3. Phenotypes of parental lines: (a) Phenotypes of restorer line GZ9399R and CMS line G46A; (b) Floret with the palea, lemma and filament elongation during flowering time; (c) Stigma length, stigma width and style length for the CMS line G46A; (d) Anther length and width under microscope; (e, f) Pollen grains stained with I-KI for G46A and GZ9399R, respectively.

As the pollen fertility estimated for restorer lines, also pollen sterility \% was recorded for CMS line G46A and the values were $100 \%$ and $99.70 \%$ under 2015 and 2016 seasons, respectively (Fig. 3e). Many traits contribute to hybrid rice seed production efficiency and panicle exsertion rate $(\%)$ and stigma exsertion rate (\%) are two of them that increasing the cross pollination and enhancing hybrid seed set production. The mean performance of these traits was 58.45 and $63.75 \%$ for panicle exsertion rate $(\%)$ and 10.73 and $11.42 \%$ for stigma exsertion rate $\%$ under both seasons, respectively. Besides floral traits, flag leaf length and flag leaf width were measured in the parental lines (G46A and GZ9399R) during the two seasons. The flag leaf length for GZ9399R was higher than those of CMS lines while; the flag leaf width was wider for the CMS line G46A than the restorer line. The mean performance of most floral traits in this study revealed values that were similar to those reported by Hasan et al. (2014) and Marathi and Jena (2015).

Performance of agro-morphological traits of hybrid and check variety: Agro-morphological characterization of days to heading, plant height, panicle length, panicle weight, 1000grain weight, number of panicles/plant, spikelet fertility rate (\%) and grain yield for the newly developed hybrid combination in comparison to the check variety Giza 178was measured and showed considerable range of variation for each of the trait (Fig. 4). The development and adoption of new rice hybrids with high-yielding and early maturing would save time, land and water for rice production in the future (Farooq et al., 2009). The hybrid (G46A/GZ9399R) recorded highly significant differences compared with the standard variety Giza 178 under both seasons.

On the contrary, this hybrid showed undesirable results in plant height where gave highly significant value in 2016 and significant value in 2017 compared with the standard check. The semi-dwarf rice plants are desirable and required in rice breeding program to appropriate the mechanical harvesting and escape lodging (Shimaru, 2008). For rice yieldsupporting traits, panicle length, panicle weight, 1000-grain weight and number of panicles/plant, the new hybrid showed highly significant differences compared with Giza 178 under both seasons for these traits, unlike spikelet fertility $\%$ which was less in terms of the new hybrid compared with the standard check. Likewise, highly significant differences in grain yield/ha were found among the new hybrid and the inbred variety Giza 178 under both seasons (Figure 4). This finding is agreement with the idea of IRRI that the yield advantage for hybrid rice is $20-30 \%$ more than the conventional varieties if both had been assessed under the same environments (Virmani and Kumar, 2004). The high production of yield in rice hybrid varieties could be attributed to significant producing a high number of panicles/plant, panicle weight, 1000-grain weight and number of filled grains/panicle (Anis et al., 2016d). Pruneddu and Spanu (2001), Mondal et al. (2005) and Sarkar et al. (2016) reported that the hybrid rice produced higher number of panicles/plant and higher number of filled grains/panicle also which ultimately showed higher grain yield/ha. Also reported that hybrid rice varieties produces produced long roots and broad leaves that enable them to take up more nutrients and suited 
to existing climatic condition and finally produced more grains/panicle and then give gave a high yield.
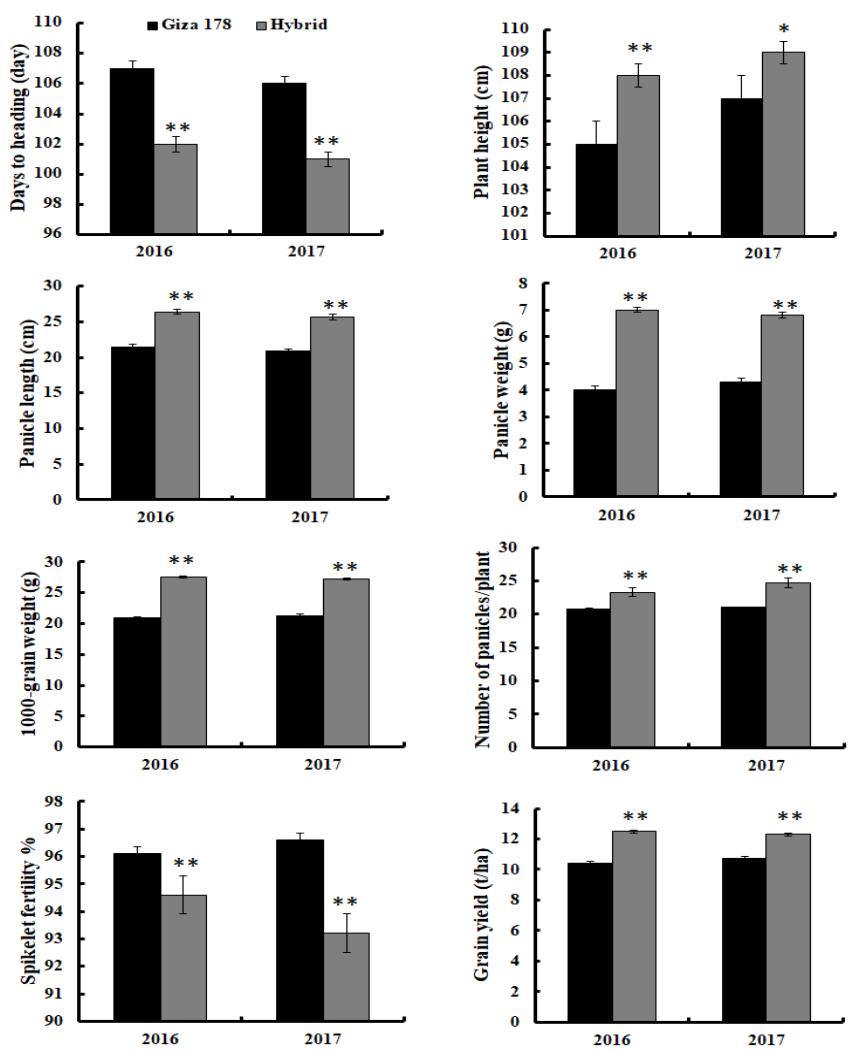

Figure 4. Performance evaluation of the hybrid and check variety Giza 178 under two rice growing seasons 2016 and 2017.

Grain quality characteristics of hybrid and check variety: Conspicuously, Table 3 and Fig. 5 shows that the mean values of milled grains length varied from short (5.16 and $5.20 \mathrm{~mm})$ in Giza 178 as check variety in both seasons, to medium (6.55 and 6.59) in G46A/GZ9399R (Hybrid) in two seasons, respectively. Width of milled grains varied from (2.21 and

$2.22 \mathrm{~mm}$ ) in Giza 178 to $(2.33$ and $2.36 \mathrm{~mm})$ in the hybrid (G46A/GZ9399R). Furthermore, milled grain shape was bold in both genotypes, Giza 178 and G46A/GZ9399R; their estimated values were $(2.37,2.36,2.85$ and $2.90 \mathrm{~mm}$ grain shape in two seasons, respectively). The short milled grain length and bold grain shape are preferred to Egyptian consumers. Manifestly, the results in Table 3 illustrated that the estimated mean values of hulling (\%) varied from heavy husks $(79.63$ and $79.81 \%)$ in Giza 178 to light husks $(81.71$ and $81.42 \%$ ) in G46A/GZ9399R. while, high milling return was recorded in G46A/GZ9399R, all estimated values exceeded $70 \%$. However, G46A/GZ9399R rice hybrid had the highest head rice percentage (63.23 and 62.94\%) in two seasons, while, low estimates were observed in Giza 178 (65.23 and $64.60 \%)$. Compared to the Egyptian commercial hybrid 1, G46A/GZ9399R was the best for most of the grain quality traits.
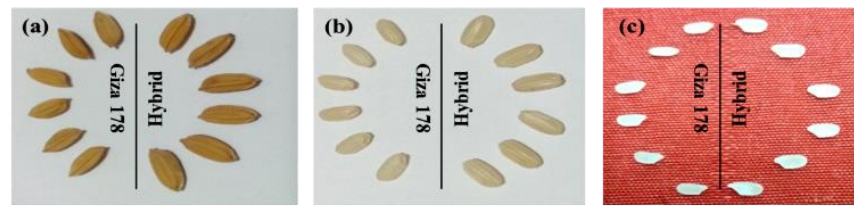

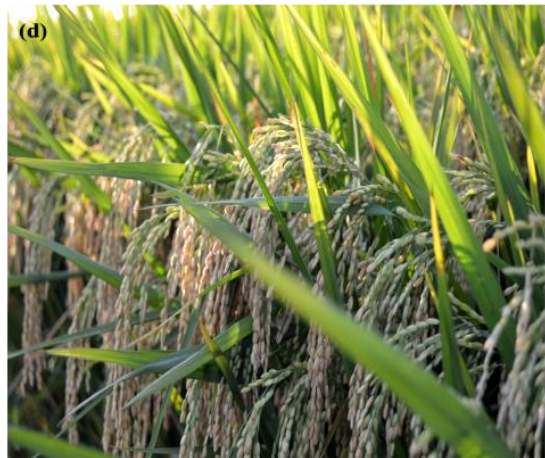

Hybrid

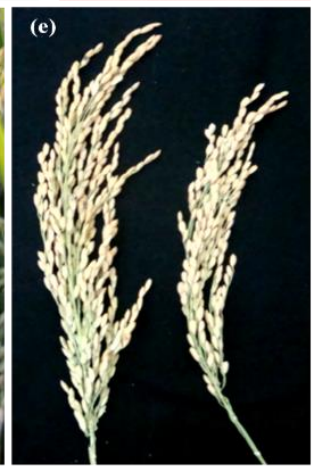

Hybrid Giza 178

Figure 5. Grain size and shape of new hybrid combination and check Giza 178 (a, b, c); Field view of the new promising hybrid (d);

Table 3. Mean performance and standard deviation of grain quality traits for hybrid and check variety.

\begin{tabular}{|c|c|c|c|c|c|}
\hline \multirow[t]{2}{*}{ Traits } & \multicolumn{2}{|c|}{ Giza 178 (Check) } & \multicolumn{2}{|c|}{ G46A/GZ9399R (Hybrid) } & \multirow{2}{*}{$\begin{array}{l}\text { Hybrid } \\
\text { feature }\end{array}$} \\
\hline & 2016 & 2017 & 2016 & 2017 & \\
\hline Grain length (mm) & $5.20 \pm 0.32$ & $5.16 \pm 0.58$ & $6.55 \pm 0.08$ & $6.59 \pm 0.10$ & - \\
\hline Grain width (mm) & $2.21 \pm 0.05$ & $2.22 \pm 0.01$ & $2.33 \pm 0.06$ & $2.36 \pm 0.04$ & + \\
\hline Grain shape (mm) & $2.37 \pm 0.02$ & $2.36 \pm 0.04$ & $2.85 \pm 0.11$ & $2.90 \pm 0.32$ & + \\
\hline Hulling $(\%)$ & $79.63 \pm 1.02$ & $79.81 \pm 0.81$ & $81.71 \pm 0.91$ & $81.42 \pm 0.86$ & + \\
\hline Milling (\%) & $69.51 \pm 0.22$ & $69.33 \pm 0.10$ & $70.10 \pm 0.47$ & $70.87 \pm 0.58$ & + \\
\hline Head rice $(\%)$ & $63.23 \pm 0.03$ & $62.60 \pm 0.00$ & $65.23 \pm 1.20$ & $64.94 \pm 1.07$ & + \\
\hline Elongation (\%) & $0.36 \pm 0.04$ & $0.37 \pm 0.01$ & $0.46 \pm 0.01$ & $0.47 \pm 0.07$ & + \\
\hline Gelatinization Temperature & $6.46 \pm 0.48$ & $6.50 \pm 0.20$ & $5.91 \pm 0.21$ & $6.09 \pm 0.66$ & + \\
\hline Gel consistency & $87.68 \pm 1.52$ & $88.15 \pm 0.85$ & $70.52 \pm 1.03$ & $69.90 \pm 1.91$ & + \\
\hline Amylose content $(\%)$ & $18.02 \pm 0.81$ & $17.07 \pm 0.75$ & $19.46 \pm 0.12$ & $19.97 \pm 0.19$ & - \\
\hline
\end{tabular}


Comparison of panicle between the new hybrid and the standard check Giza 178 (e).

Furthermore, it is customary to use liner expansion as the measure of grain elongation, but this appears to be a poor measurement, as it fails to consider the widthwise swelling, which independent of lengthwise is swelling. Hence, proportionate change in the $\mathrm{L} / \mathrm{W}$ ratio of grain on cooking, as detailed under materials and methods was taken as the measure of elongation in the genotypes (Biswas et al., 2013). The results indicated a wide variation for this trait, in both genotypes studied, and the values ranged from 0.46 to 0.47 mm (medium grain elongation) in G46A/GZ9399R while, in Giza 178, that had low grain elongation (from 0.36 to 0.37 $\mathrm{mm}$ ). Gelatinization temperature, as measured by alkali digestion scores, was found to low in both rice genotypes; namely, Giza 178 and G46A/GZ9399R, indicating that the rice genotypes under study needed a short time when cooked, which saved energy. Gel consistency largely varied from soft gel (length of gel, 61-80 mm) in G46A/GZ9399R to very soft gel consistency (length of gel 81-100 mm) in Giza 178, which remains a soft grain for a long time after cooking. Low amylose content was detected for both studied genotypes; their estimated values varied from 18.02 and $17.07 \%$ in Giza 17.8 to $19.46 \%$ and $19.97 \%$ in G46A/GZ9399R in 2016 and 2017, respectively. Genotypes with low amylose content are moist, sticky and glossy when cooked, and readily split and disintegrate when over cooked. Further, the low amylose content is preferred to Egyptian consumers (Badawy and Mahgoub, 2015). Numerous investigations were done for appearance, physical and physicochemical properties for hybrid rice combinations (Babu et al., 2013; Gampala et al., 2015; Anis and Gharib, 2016).

Assessment of genetic purity of hybrid and their parental lines: Ten microsatellite markers, RM258, RM154, RM70, RM247, RM331, RM226, RM204, RM297, RM337 and RM164 were used for analysis the genetic purity of rice hybrid G46A/GZ9399R. One allele amplified in a hybrid when the parental lines were monomorphic for especially microsatellite locus and two alleles were detected in a hybrid when polymorphism was cleared among the male and female parents. Out of 10 SSR markers, three markers RM154, RM331 and RM297 showed polymorphism between G46A and GZ9399R, whereas seven markers (RM258, RM70, RM247, RM226, RM204, RM337 and RM164) expressed non-polymorphism among the parental lines. Then, the three polymorphic SSR markers (RM154, RM331 and RM297) were assessed using DNA bulk of the hybrid and its parental lines. For all three markers, parents showed one allele whereas the hybrid showed two the parental lines alleles indicating the heterogeneity of the hybrid (Fig. 6 a,b,c).

To test the reliability of the polymorphic markers (RM154, RM331 and RM297), the marker RM297 was confirmed using DNA from 15 individual plants of the hybrid. All the individual $F_{1}$ hybrid plants showed both the parental lines alleles, confirming the utility of these markers in genetic purity assessment of the hybrid (Fig. 6 d). From another side, in the trials during the two evaluation seasons, assessment of genetic purity for hybrid and their parental lines was conducted based on morphological characterization including, days to heading, plant height, panicle length, panicle weight, 1000-grain weight, number of panicles/plant, spikelet fertility $\%$ and grain yield and some of floral traits in parental lines (Table 1; Fig. 4). The traits of most $F_{1}$ individual plants showed no off-types were obtained in the hybrid (G46A/GZ9399R) and the parental lines were fairly constant during both seasons, which were also further supported by the molecular marker testing. Similar studies have also been done by Tamilkumar et al. (2009), Kumar (2012), Sudharani et al. (2013) and Bora et al. (2016).

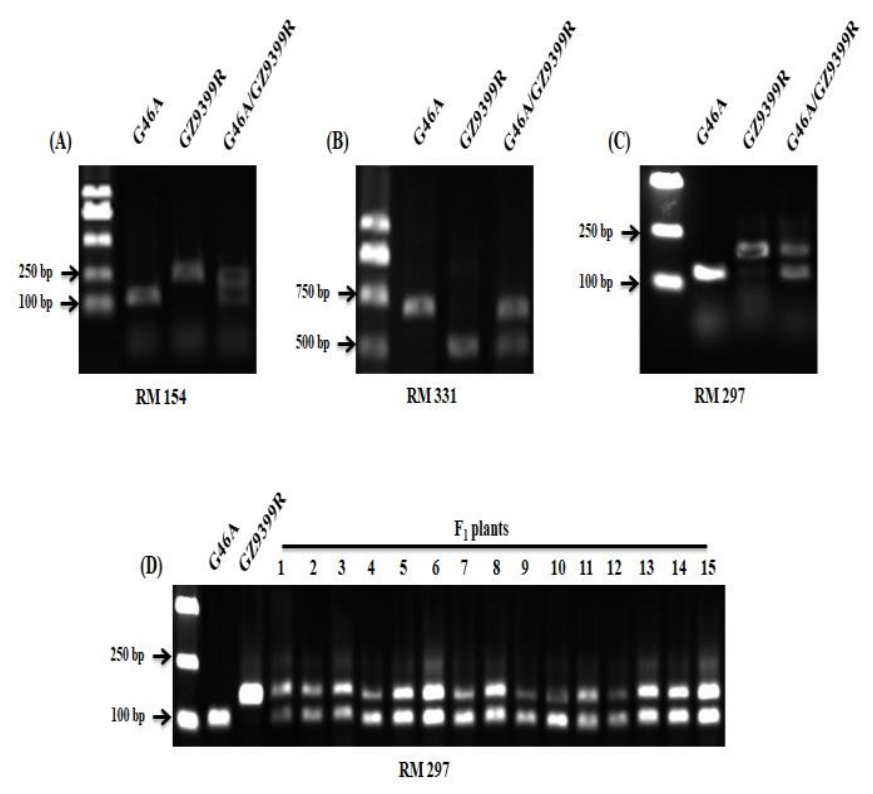

Figure 6. Genetic purity testing of G46A/GZ9399R hybrid using polymorphic SSR markers: (A, B, C) Polymorphism profile between hybrid and its parental lines using bulked DNA by RM154, RM331 and RM297 markers, respectively; (D) Confirming the hybrid purity in the individual F1 by RM297 marker.

Conclusion: Developing new rice hybrids with high-yielding and superior grain quality properties are the most essential aim to enhance food security and achieve consumer preference. Apparently, the new promising hybrid G46A/GZ9399R showed its superiority in most studied traits compared to the commercial check variety Giza 178. This hybrid was very early maturing, widely adapted and it provided yield advantage $20.19 \%$ more than the conventional variety. In parallel with this, the assessment of genetic purity established the SSR markers of RM154, RM331, RM297 and 
amplified alleles specific to differentiate parental lines of G46A/GZ9399R hybrid.

\section{REFERENCES}

Abd Allah, R.M. 2008. Genetical and morphological studies on environmental genetic and cytoplasmic male sterility lines in rice. M.Sc. Thesis, Fac. of Agric., Mansoura Univ. Egypt.

Al-Ashkar, I.M., E.I. Zaazaa, A. EL Sabagh and C. Barutçular. 2016. Physio-biochemical and molecular characterization for drought tolerance in rice genotypes at early seedling stage. J. Exp. Biol. Agric. Sci. 4:675687.

Anis, G. and A. El-Sherif. 2014. Developing new hybrids of rice to boost food security in Egypt. Plant Biology Europe FESPB/EPSO Congress, June 22-26, Dublin, Ireland. pp. 278.

Anis, G.B. 2013. Development and evaluation of new restorer and maintainer lines and their relationship to heterosis in rice. A PhD Thesis, Agric. Sci., Genetics Dept., Mansoura Univ., Egypt.

Anis, G.B., H.F. El-Mowafi, A. El-Sherif, H. Freeg, E. Arafat and A. EL Sabagh. 2017. Utilizing two line system in hybrid rice (Oryza sativa L.) and potential yield advantage under Egyptian conditions. Agric. Adv. 6:398406.

Anis, G.B., M.M. Kamara and M.A. El-Sayed. 2016c. Genetic analysis of some quantitative traits in hybrid rice with utilizing cytoplasmic genetic male sterility system. Egypt. J. Agron. 38:241-256.

Anis, G., A. EL Sabagh, A. El-Badry and C. Barutçular. 2016b. Improving grain yield in rice (Oryza sativa L.) by estimation of heterosis, genetic components and correlation coefficient. Int. J. Cur. Res. 8:25080-25085.

Anis, G.B., E.L. Namaky, I.M. Ashkar, C. Barutçular and A. EL Sabagh. 2016a. Yield potential and correlation analysis of some rice hybrids for yield and its component traits. J. Anim. Plant Sci. 30:4748-4757.

Anis, G.B. and H.S. Gharib. 2016. Physical and physicochemical properties for selected hybrid rice combinations derived from three-line system. J. Plant Prod. Mansoura Univ. 7:1155-1163.

Ansari, M.U.R., T. Shaheen, S. Bukhari and T. Husnain. 2015. Genetic improvement of rice for biotic and abiotic stress tolerance. Turk. J. Bot. 39:911-919.

Bakht, J., M. Ghaffar, M. Shafi, A. Latif and S. Khan. 2011. Determination of genetic diversity of different barley genotypes grown in Khyber Pakhtun Khwa using RAPD markers. Pak. J. Bot. 43:2491-2495.

Babu, V.R., K. Shreya, K.S. Dangi, G. Usharani and P. Nagesh. 2013. Evaluation of popular rice (Oryza sativa L.) hybrids for quantitative, qualitative and nutritional aspects. Int. J. Sci. Res. Public 2:1-8.
Badawy, S.A and S.A. Mahgoub. 2015. Study of agronomical and technological quality characteristics of some special Egyptian rice varieties. Egyp. J. Agron. 37:121-136.

Bastawisi, A.O., H.F. El-Mowafi, M.I. Abo Youssef, A.E. Draz, I.R. Aidy, M.A. Maximos and A.T. Badawi. 2003. Hybrid rice research and development in Egypt. In: S.S. Virmani, C.X. Mao and B. Hardyl (eds.), Hybrid Rice for Food Security Poverty Alleviations, and Environmental Protection, IRRI. $4^{\text {th }}$ Int. Symposium on Hybrid Rice 1417 May 2002, Hanoi, Vitnam; pp.257-264.

Bhavsar, S., T. Solanki, S. Amin and N. Jain. 2017. Assessment of genetic purity of parental lines of hybrid rice using DNA-based markers. J. Biol. Sci. 15:59-69.

Biswas, B.K., N. Alam, J.A.T. da Silva, M.M. Haque, M.A. Azad and M.K. Hossain. 2013. Framework for selecting suitable indicators to improve yield potential in fine rice (Oryza sativa L.). Int. J. Plant Breed. 7:42-49.

Bora, A., P.R. Choudhury, V. Pande and A.B. Mandal. 2016. Assessment of genetic purity in rice (Oryza sativa L.) hybrids using microsatellite markers. Biotechnol. 6:1-7.

Cheng, S.H., J.Y. Zhuang, Y.Y. Fan, J.H. Du, X.D. Zhan, Y.Y. Fan and D.F. Zhu. 2007. Progress in research and development on hybrid rice: a super domesticate in China. Ann. Bot. 100:959-966.

Cottyn, B. 2002. Bacteria associated with rice seed from Philippine farmer's fields. Int. Rice Res. Institute. College, Laguna, Philippines.

Cottyn, B., J. Debode, E. Regalado, T.W. Mew and J. Swings. 2009. Phenotypic and genetic diversity of rice seedassociated bacteria and their role in pathogenicity and biological control. J. Appl. Microb. 107:885-897.

El-Badawy, O.A. 2016. Genetic and molecular studies on fertility restoration ability of hybrid rice. A PhD Thesis Agric. Sci., Genetics Dept., Mansoura Univ., Egypt.

El-Mowafi, H.F., A.O. Bastawisi, A.F. Abdelkhakek, K.A. Attia, R.A.A. EL.Namaky and M.H. Ammar. 2008. Hybrid rice tchnology in Egypt . In: F. Xie, C.X. Mao and B. Hardy (eds.), Hybrid Rice for Food Security. Proc. $5^{\text {th }}$ Int. Symp. Hybrid Rice, 11-15 Sept., Changsha, China.

El-Mowafi, H.F., A.R. Ahmed and G.B. Anis. 2015. Identification of restorers and maintainer lines based on CMS and EGMS systems for developing rice hybrids in Egypt. Egypt J. Plant Breed. 19:1865-1872.

El-Mowafi, H.F., A.O. Bastawisi, M.I. Abou Youssef and F.U. Zaman. 2005. Exploitation of rice heterosis under Egyptian conditions. Egypt. J. Agric. Res. 389:143-166.

El-Namaky, R. 2018. The genetic variability of floral and agronomic characteristics of newly-bred cytoplasmic male sterile rice. Agriculture 8:5-68.

Farooq, M., N. Kobayashi, A.Wahid, O. Ito and S.M.A. Basar. 2009. Strategies for producing more rice with less water. Adv. Agron. 101:351-388.

Galal, O.A., M.I. Abo-Youssef, M.M. Abdelaziz, A.T. Gharib and S.A. Dora. 2014. Assessment of genetic purity of 
some hybrid rice parental lines using protein profile and fertility restorer gene linked markers. Int. J. Biotechnol. Res. 2:075-088.

Gampala, S., V.J. Singh and S. Chakraborti. 2015. Analysis of variability and genetic parameter for grain quality attributes in high yielding rice (Oryza sativa L.) genotypes. The Ecoscan. 9:411-414.

Ghori, N., M. Hayat and S. Davino. 2016. Genetic diversity and evolutionary analysis of Citrus Tristeza Virus p20 gene in Pakistan: insights into the spread and epidemiology. pp. 75-82. incomplete

Hassan, H.M., G.B. Anis and I.H. Abou El-Darag. 2017. Utilization of wide adaptability of some imported rice (Oryza sativa L.) genotypes for weed suppression and fertility restoration ability. The $11^{\text {th }}$ International Plant Breeding Conference, October 17-18, Kafr El-Sheikh Univ., Egypt; pp.231-245.

Hasan, M.J., U. Kulsum, M.H. Rahman, A. Akter and A. Shamsuddin. 2014. Comparative study of floral charactaristics in the component lines of hybrid rice (Oryza sativa L.). Bangladesh J. Bot. 43:1-8.

IRRI. 1996. Standard evaluation system for rice. International Rice Research Institute (IRRI), P.O. Box 933, 1099 Manila, Philippines.

Ishikawa, R., T. Watabe, R. Nishioka, P.T. Thanh and T. Ishii. 2017. Identification of quantitative trait loci controlling floral morphology of rice using a backcross population between Common cultivated rice, Oryza sativa and Asian wild rice, O. rufipogon. Amer. J. Plant Sci. 8:734-744.

Khush, G.S. and D.S. Brar. 2002. Biotechnology for rice breeding: Progress and potential impact. Proceeding of the $20^{\text {th }}$ Session of the International Rice Commission, $23^{\text {th }}-26^{\text {th }}$ July, Bangkok, Thailand.

Kumar, M.C. 2012. Utilization of SSR markers for seed purity testing in popular rice hybrids (Oryza sativa L.). Ann. Plant. Sci. 1:1-5.

Luo, Q.J., L. Chen and L.J. Luo. 2005. Comparison of three rapid methods of DNA extraction from rice. Mol. Plant Breed. 3:749-752.

Mahalingam, A., R. Saraswathi, J. Ramalingam and T. Jayaraj. 2013. Genetics of floral traits in cytoplasmic male sterile (CMS) and restorer lines of hybrid rice (Oryza sativa L.). Pak. J. Bot. 45:1897-1904.

Mao, C.X., S.S. Virmani and I. Kumar. 1996. Technological innovations to lower the cost of hybrid rice seed production. In: Advance in hybrid rice technology. Proc.Third Int. Symp.Hybrid Rice, Directorate of Rice Research, Hyderabad, India.

Marathi, B. and K.K. Jena. 2015. Floral traits to enhance outcrossing for higher hybrid seed production in rice: present status and future prospects. Euphytica 201:1-14.

Miura, K. 2011. The role of QTLs in the breeding of highyielding rice. Trends Plant Sci. 16:319-326.
Mondal, M.M.A., A.F.M.S. Islam and M.A. Siddique. 2005. Performance of 17 modern transplant aman cultivar in the north region of Bangladesh. Bangladesh J. Crop Sci. $16: 23-29$.

Mondo, V.H., A.S. Nascente, P.C.F. Neves, J.E. Taillebois and M.O.A.C. Neto. 2016. Flowering synchronization in hybrid rice parental lines. Aust. J. Crop Sci. 10:12131221.

Oka, H.I. 1988. Origin of Cultivated Rice. Jpn. Sci. Press, Eelesvier, Tokyo; p.254.

Panse, V.G. and P.V. Sukhatme. 1984. Statistical methods for agricultural research workers. ICAR, New Delhi; pp.145152.

Pruneddu, G. and A. Spanu. 2001. Varetal comparison of rice in Sardinia. Dipartimentodi Science AgroomicheGenetica vegetable Agraria, Universitadegli, Italy Informatore-Agraria 57:47-49.

Phukan, A., P.K. Barua, D. Sarma and S.D. Deka. 2018. Study on floral traits and seed setting in parental lines of hybrid rice during early ahu and kharif seasons. Ind. J. Gene. P.B. (The). 78:285-291.

RRTC. 2013. National Rice Research Program: Final results of 2012 growing season. Sakha, Egypt.

Sabar, M., M. Akhter, F.A. Faiz, S.S. Ali and M. Ahmad. 2007. Identification of restorers and maintainers for developing hybrid rice. J. Agric. Res. 45:19-24.

Sarkar, S.C., M. Akter, M.R. Islam and Md. M. Haque. 2016. Performance of five selected hybrid rice varieties in Aman season. J. Plant Sci. 4:72-79.

Shimaru, K., E. Togawa, E., T. Ookawa , T. Kashiwagi ,Y. Madoka and N. Hirotsu . 2008. New target for rice lodging resistance and its effect in a typhoon. Planta 227:601-609.

Sindhu, J.S. and I. Kumar. 2002. Quality seed production in hybrid rice. Proc.20th Session of International Rice Commission, (IRC' 02), Bangkok, Thailand.

Sudharani, M., K.R. Lakshmi, A.V. Reddy, K. Bharthi and N.R. Raju. 2013. Use of DNA polymorphism for characterization and assessment of genetic purity testing in rice hybrids (Oryza sativa L.). Electron. J. Plant Breed. 2:1113-1118.

Suzuki, S. 1981. Cold tolerance in rice with special reference to the floral characters. 1. Varietal difference in anther and stigma lengths and the effect of planting densities on these characters. Jap. J. Breed. 31:57-64.

Tamilkumar, P., R. Jerlin, N. Senthil, K.N. Ganesan, R.J. Jeevan and M. Raveendran. 2009. Fingerprinting of rice hybrids and their parental lines using microsatellite markers and their utilization in genetic purity assessment of hybrid rice. Res. J. Seed Sci. 2:40-47.

USDA. 2016. United States Department of Agriculture, Commodity Intelligence Report, 22 January. 
Virmani, S.S. and D.S. Athwal. 1973. Genetic variability for floral characters influencing outcrossing in Oryza sativa L. Crop Sci. 13:66-67.

Virmani, S.S. and I. Kumar. 2004. Development and use of hybrid rice technology to increase rice productivity in the tropic. Int. Rice Res. Note 19:10-19.

Virmani, S.S. 1996. Hybrid rice. Adv. Agron. 57:378-462.

Virmani, S.S., B.C. Virktamath, C.L. Casal, R.S. Toledo, M.T. Lopez and J.O. Manalo. 1997. Hybrid rice breeding manual, International Rice Research Institute, Philippines.
Vishwakarma, A., J.K. Singh, R.K. Singh and A.L. Jat. 2016. Productivity and profitability of rice (Oryza sativa) hybrids as influenced by date of transplanting and age of seedling under system of rice intensification. Ind. J. Agron. 61:315-320.

Yang, G.P., M.A. Saghai Maroof, C.G. Xu, Q. Zhang and R.M. Biyashev. 2006. Comparative analysis of microsatellite DNA polymorphism in landraces and cultivars of rice. Mol. Genet. 245:187-94.

Yuan, L.P. 2004. Hybrid Rice for Food Security in the World. FAO Rice Conference, Rome, Italy. 